Dicle Tıp Dergisi / Dicle MedicalJournal (2017) 44 (4) : 315-324

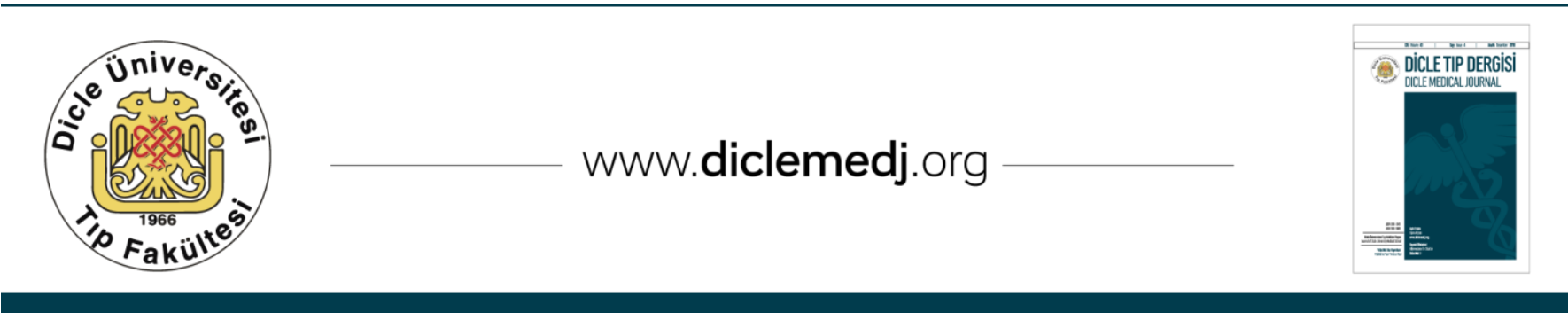

Özgün Araștırma / Original Article

\title{
Apoptotic Effects of Reduced Brain Derived Neurotrophic Factor (BDNF) on Mouse Liver and Kidney
}

\author{
Berna Tezcan1, Gülay Hacıŏglu², Selcen Aydın Abidin³, İsmail Abidin ${ }^{4}$ \\ 1 Department of Histology and Embryology, Faculty of Medicine, Giresun University, Giresun, Turkey ORCID: 0000-0002-7410-9485 \\ 2 Department of Physiology, Faculty of Medicine, Giresun University, Giresun, Turkey ORCID: 0000-0002-8528-2371 \\ 3 Department of Biophysics, Faculty of Medicine, Karadeniz Teknik University, Trabzon, Turkey ORCID: 0000-0002-5843-5539 \\ 4 Department of Biophysics, Faculty of Medicine, Karadeniz Teknik University, Trabzon, Turkey ORCID: 0000-0003-2510-9718
}

Received: 02.03.2017; Revised: 14.08.2017; Accepted: 05.10.2017

\begin{abstract}
Objective: Brain-derived neurotrophic factor (BDNF) promotes the development and differentiation of neurons and synapses, as well as neuronal survival, by acting on specific neuronal groups in the central and peripheral nervous systems. However, the direct effect of BDNF on apoptosis in peripheral tissues is not known. The aim of this study was to investigate the relationship between BDNF and apoptosis, and the density and distribution of BDNF receptors in liver and kidney tissues by histological and immunehistochemical methods.

Methods: Seven wild-type and 7 BDNF heterozygous (reduced BDNF levels) male mice were used in the study. Caspase-3 and TUNEL immunehistochemical stainings were performed in order to investigate the presence of apoptosis in the liver and kidney tissues of the studied groups. Apoptosis-entering cells were counted and the groups were compared. Concentration and distribution of BDNF receptors, tropomyosin-related kinase B (TrkB) and nerve growth factor receptor p75 (NGFR p75), in liver and kidney tissues were also examined by immunehistochemical analyzes.

Results: As a result of Caspase-3 and TUNEL immunehistochemical staining, more cells were counted to enter the apoptotic process in sections of BDNF heterozygous group compared to control group $(\mathrm{p}<0.0001)$. In both groups TrkB and NGFR p75 receptors in liver and kidney tissues were determined in trace amounts, but there was no difference in intensity and distribution between the studied groups.

Conclusion: According to our histological and immunehistochemical stainings and statistical analysis of cell count between groups, it was found that BDNF is protective against apoptosis in liver and kidney. The lack of difference between the studied groups in terms of intensity and distribution of BDNF receptors, suggests that BDNF receptor distribution in the liver and kidney tissues may be different from the nervous system or that BDNF may differ in affinity for these receptors.
\end{abstract}

Keywords: BDNF, Apoptosis, Liver, Kidney, Immunohistochemistry

DOI: $10.5798 /$ dicletip.

Yazışma Adresi / Correspondence: Berna Tezcan, Biology Department of Counsil of Forensic Medicine, İzmir, Turkey e-mail: bernatezcan@hotmail.com 


\title{
Azaltılmış Beyin Kaynaklı Nörotrofik Faktörün (BDNF), Fare Karaciğer ve Böbrek Dokusuna Apoptotik Etkileri
}

\begin{abstract}
Özet
Amaç: Beyin kökenli nörotrofik faktör (BDNF), merkezi ve periferik sinir sisteminde belirli nöron grupları üzerine etki ederek, nöron ve sinapsların gelişimini ve farklılaşmasını, bunun yanında nöronal sağkalımı desteklemektedir. Periferik dokularda ise BDNF'nin apoptoz ile direkt ilişkisi bilinmemektedir. Bu çalışmada, karaciğer ve böbrek dokularında BDNF'nin apoptoz ile ilişkisi ve bu dokulardaki BDNF reseptörlerinin yoğunluk ve dağılımının histolojik ve immünohistokimyasal yöntemler kullanılarak araştırılması amaçlanmıştır.

Yöntemler: Araştırmada 7 adet yabanıl tip ve 7 adet BDNF heterozigot (BDNF düzeyleri yarı yarıya azaltılmış) erkek fare kullanılmıştır. Karaciğer ve böbrek dokusunda apoptozun varlığını araştırmak amacıyla Kaspaz-3 ve TUNEL immünohistokimyasal boyamaları gerçekleștirilmiş ve apoptoza giren hücreler sayılarak gruplar arası karşılaștırma yapılmıștır. BDNF reseptörleri olan tropomiyozin-ilişkili kinaz B (TrkB) ve nerve growth factor receptor p75 (NGFR p75)'in karaciğer ve böbrek dokularındaki yoğunluk ve dağılımı da immünohistokimyasal analizler ile incelenmiștir.

Bulgular: Kaspaz-3 ve TUNEL immünohistokimyasal boyamaları sonucunda kontrol grubuna göre, BDNF heterozigot gruba ait kesitlerde daha fazla sayıda apoptoza girmiş hücre sayılmıștır ( $\mathrm{p}<0.0001)$. İmmünohistokimyasal boyamalar sonucunda karaciğer ve böbrek dokusunda TrkB ve NGFR p75 reseptörlerinin eser miktarda bulunduğu saptanmış, ancak çalışma grupları arasında yoğunluk ve dağılımları açısından farklılık gözlenmemiștir.

Sonuç: Yapılan histolojik ve immünohistokimyasal boyamalar ve gruplar arası hücre sayımına ait istatistiksel analizler sonucunda BDNF'nin karaciğer ve böbrekte apoptoza karşı koruyucu etkisinin olduğu saptanmıştır. BDNF reseptörlerinin yoğunluğu ve dağılımı açısından çalışma grupları arasında fark bulunmaması, karaciğer ve böbrek dokusunda BDNF reseptör dağılımının sinir sisteminden farklı olabileceğini veya BDNF'nin bu reseptörlere afinitesinde farklılıklar olabileceğini düşündürmüştür.
\end{abstract}

Anahtar kelimeler: BDNF, Apoptoz, Karaciğer, Böbrek, İmmunohistokimya

\section{INTRODUCTION}

Neurotrophins are members of the polypeptide growth factors family that affect the proliferation, differentiation, survival and death of neurons and other cells ${ }^{1,2}$. Brain-derived neurotrophic factor (BDNF) is the second member of this family, defined in $1982^{3}$. Others are nerve growth factor (NGF), neurotrophin-3 (NT-3), neurotrophin-4/5 (NT-4/5) and neurotrophin-6 (NT-6) ${ }^{4-6}$. The activity of neurotrophins depends on their availability levels, their affinity for binding to transmembrane receptors, and the induction of signaling pathways after receptor activation. BDNF is a secretory protein of the neurotrophin family encoded by the BDNF gene in humans ${ }^{1,7}$. BDNF promotes the development and differentiation of neurons and synapses, as well as neuronal survival, by acting on specific groups of neurons in both the central and peripheral nervous systems ${ }^{8,9}$. An important neurotrophic factor that affects the neurons' life, growth and function, provides synaptic stabilization, synaptic function, regulates axon and dendritic branching 1,8 . In addition to its classic role on neuronal growth, survival and differentiation, BDNF has been reported to alter lipid oxidation in muscle cells, affecting blood glucose and lipid levels ${ }^{10}$. These effects are the reason why BDNF is also defined as metabotropin as well as being neurotrophin ${ }^{11}$. Furthermore, in recent study it has been found that BDNF also has protective effects against immobilization stress by reducing oxidative stress damage ${ }^{12}$. BDNF expression was primarily detected in the hippocampus, cortex, and basal forebrain, areas where the brain performs learning, memory, and high-level thinking tasks ${ }^{13}$. Later, it was found that BDNF was presented not only in the brain but also in peripheral tissues such as skeletal muscle, 
adipose tissue, kidneys, liver and prostate $5,10,11,14-21$.

Two types of BDNF receptors have been identified: activation of the nerve growth factor receptor p75 (NGFR p75) receptors leads to apoptosis, while activation of tropomyosinrelated kinase $\mathrm{B}$ (TrkB) receptors leads to cellular proliferation and differentiation $15,22,23$. Studies have shown that BDNF has high affinity for TrkB receptors, whereas it has low affinity for NGFR p75 receptors ${ }^{24}$. It has been noted that the BDNF and TrkB receptors are also expressed in many non-neuronal tissues including muscle, thymus, heart, vascular smooth muscle cells, lung and spleen ${ }^{19,25}$.

Expression of neurotrophins and neurotrophin receptors in non-neuronal tissues is associated with migration, proliferation, differentiation, and tissue restructuring of target cells ${ }^{14}$. The increase in the expression of BDNF and its receptors in cells has been demonstrated by clinical studies generally in pathological conditions or after damage $\mathrm{11}^{1,14,15,20}$.

In multicellular organisms, the number of cells increased by cell division is compensated by cell death. If, in an organism, a cell is no longer needed, intracellular messenger systems are activated and the cell suicide process is initiated. This suicide process occurs in apoptosis or programmed cell death 26,27 .

Apoptotic cells are constantly formed in some tissues and cells of the organism and this formation continues for life. Thus, death (apoptosis) and remodeling (mitosis) persist in these tissues in a dynamic balance to form tissue homeostasis ${ }^{28,29}$.

Like other neurotrophic factors during development, BDNF protects developing neurons by inhibiting apoptosis ${ }^{30}$. Neuroprotective effects of BDNF in hippocampus, especially in ischemic injury, have been reported ${ }^{31,32}$. The irreversible cell death is caused by the activation of Caspases, especially the Caspase- $3^{33}$. It has been found that BDNF prevents glutamate-induced apoptotic cell death by reducing the efficacy of Caspase-3 like enzymes ${ }^{34}$.

In the literature, the apoptosis regulatory effects of BDNF were generally studied in the central nervous system. In the peripheral tissues, some studies on BDNF and/or its receptors have been performed after pathological conditions or tissue damage. It is not known how BDNF is directly related to apoptosis and how BDNF affects apoptosis. In this study, we aimed to compare apoptosis in liver and kidney tissues of BDNF heterozygous mice and wild-type mice, and to investigate the concentration and distribution of BDNF receptors in studied groups.

\section{METHODS}

In the experiments, 10-12 week old 7 wild-type male mice (control group) and 7 BDNF heterozygous male mice (heterozygous group) were used. In BDNF heterozygous transgenic mouse model established by Korte and colleagues $^{35}$ one allele of the BDNF coding region was replaced by the neomycineresistant gene. The heterozygous mice were viable, fertile and indistinguishable from their wild type littermates. The transgenic mice were donated by Dr. Thomas Mittmann, University of Meinz, Germany to Karadeniz Technical University (KTU) in 2011. Since then the BDNF heterozygous mice are produced and kept in KTU animal facility. Verification of the transgene was done by Dr. I. Abidin and Dr. S. Aydın-Abidin by following the existance of neomicin gene with Polimerase Chain Reaction (PCR) from the tail tissue. Small pieces of tail tissue were homogenized in a lysis buffer (500 $\mathrm{mM} \mathrm{KCl}, 100 \mathrm{mM}$ Tris- $\mathrm{HCl}, 0.1 \mathrm{mg} / \mathrm{ml}$ gelatin, $0.45 \%$ Nonidet P-40, $0.45 \%$ Tween 20; and $500 \mathrm{Mg} / \mathrm{ml}$ proteinase $\mathrm{K}$, added just before lysis process). PCR primers designed to recognize $\mathrm{BDNF}$ and Neomycine were $5^{\prime}$-ACC ATA AGG ACG CGG ACT TGT AC- $3^{\prime}$ and $5^{\prime}$-GAT 
TCG CAG CGC ATC GCC TT-3', respectively. The sequence of reverse primer was $5^{\prime}$-GAA GTG TCT ATC CTT ATG AAT CGC-3'. In this study animal rights have been preserved in line with the principles of Guide for the Care and Use of Laboratory Animals and have received animal ethics approval from Giresun University local ethics committee.

Animals were perfused with $0.01 \mathrm{M}$ phosphate buffer (pH:7,4) containing 4\% formaldehyde via heart under ketamine anesthesia and liver and kidney tissues were removed and quickly fixed in 10\% neutral formol overnight. Both right and left kidneys were used in the study. For the liver, any region where the parenchyma can be clearly observed was selected. Then tissues were washed in tap water for two hours. Increased alcohol series were used to purify the tissues from water. The tissues were transparentized with xylene and paraffin blocks were prepared to allow examination the parenchyma of the livers and the cortex of the kidneys. Routine hematoxylin-eosin (H-E) staining was first applied to sections of $5 \mu \mathrm{m}$ thickness from paraffin blocks to reveal the histologic structure of the tissues.

Caspase-3 and TUNEL immunohistochemical analyses were performed to determine the apoptotic differences between studied groups. The density and distribution of BDNF receptors TrkB and NGFR p75 were also examined by immunohistochemistry.

The Caspase-3, TrkB and NGFR p75 primer antibodies and chemicals used in immunohistochemical stainings are supplied from Santa Cruz Biotechnology, Inc. (sc-2018). Immunohistochemically, avidin biotin peroxidase method was used. Firstly, deparaffinization and rehydration procedures were applied to paraffin tissue sections according to the staining protocol. Ten minutes antigen retrieval (with sodium citrate buffer in $95^{\circ} \mathrm{C}$ microwave oven) and 10 minutes $3 \%$ hydrogen peroxide incubation was performed to prevent nonspecific staining. After 60 minutes of \%1.5 blocking serum application, sections were treated with Caspase-3 (sc98785), TrkB (sc-8316) and NGFR p75 (sc8317) primer antibodies (dilution: 1:100) overnight. After washing with phosphate buffered saline (PBS), the secondary antibody and then the Avidin Biotin Complex were applied. Following PBS washing step, Peroxidase Substrate containing DAB was dropped. All sections were contrasted with hematoxylin.

The TUNEL kit was obtained from Merck Millipore (S7100). Firstly, deparaffinization and rehydration procedures were applied to paraffin tissue sections according to the staining protocol. Ten minutes antigen retrieval (with sodium citrate buffer in $95^{\circ} \mathrm{C}$ microwave oven) and 10 minutes 3\% hydrogen peroxide incubation was performed to prevent nonspecific staining. After washing with PBS, equilibration buffer, working strength TdT enzyme and working strength stop/wash buffer was used. Following PBS washing step anti-digoxigenin conjugate and peroxidase substrate was performed. All sections were contrasted with methyl green.

Cells that positive staining with Caspase- 3 and TUNEL were counted on a light microscope at a magnification of $40 \mathrm{X}$ by randomly selecting 5 areas in each section. In each section, staining for Caspase-3 and TUNEL, the ratio of positive stained cells to the total number of cells in the same field (Caspase-3 index and apoptotic index) was calculated. The Caspase- 3 index was calculated according to the following formula: [the number of Caspase-3 immunopositive cells/the number of total cells]x100. The apoptotic index was calculated according to the following formula: [the number of apoptotic cells/the number of total cells]x100. The counting of the cells was performed by two observers who were blinded to the experiment protocol. Sections stained with TrkB and NGFR 
p75 were examined histologically under light microscope.

The data was analyzed using SPSS Statistics version 17.0. Mann-Whitney $U$ test was used for between-group comparisons. The results are given as mean \pm standard deviation. Values of $\mathrm{p}<0.05$ were considered statistically significant.

\section{RESULTS}

H-E staining of the first five consecutive sections taken from paraffin tissue block of each animal was examined histologically and comparisons were made between the groups. In the H-E-stained sections, the BDNF heterozygous group showed slight deterioration in both liver parenchyma and kidney cortex tissue structure compared to the control group (Figure 1).

In the second and third consecutive sections, Caspase-3 and TUNEL immunohistochemical analyzes were performed, respectively. In both stainings, BDNF heterozygous cross-sections showed positive staining of cells with apoptosis, compared to control group (Figure 2-3). Positive stained cells were counted on a light microscope at a magnification of $40 \mathrm{X}$ by randomly selecting 5 areas in each section (Figure 4-5) and statistical evaluation by MannWhitney $U$ test (Table 1), was found to be significant $(\mathrm{p}<0.0001)$.

The ratio of Caspase- 3 positive cells to total cells (Caspase- 3 index) in BDNF heterozygous group higher than the control group both the liver and kidney tissues. The ratio of TUNEL positive cells to total cells (apoptotic index) in BDNF heterozygous group higher than the control group both the liver and kidney tissues (Figure 6-7). Statistical evaluation by MannWhitney U test (Table 1), was found to be significant $(\mathrm{p}<0.0001)$.

The statistical results show that BDNF has a protective effect against apoptosis in liver and kidney tissues.

Table 1: Statistical evaluation of the cell count and index after Caspase-3 and TUNEL immunohistochemical analyses applied to liver and kidney tissue sections ( 5 sections randomly from each animal) of Control and BDNF Heterozygous Group (40X magnification) * $\mathrm{p}<0.0001$ (compared to control group).

\begin{tabular}{llcc}
\hline \multirow{2}{*}{ Tissue } & Parameters & $\begin{array}{c}\text { Control Group }(\mathrm{n}=7) \\
\text { Mean } \pm \text { SD }\end{array}$ & $\begin{array}{c}\text { BDNF Heterozygous Group }(\mathrm{n}=7) \\
\text { Liver }\end{array}$ \\
& Caspase-3 & $10.28 \pm 1.60$ & $32.14 \pm 4.45^{*}$ \\
& Caspase-3 Index & $7.07 \pm 0.74$ & $18.60 \pm 2.39^{*}$ \\
& TUNEL & $10.00 \pm 2.16$ & $33.00 \pm 3.05^{*}$ \\
& Apoptotic Index & $6.98 \pm 1.49$ & $19.41 \pm 1.62^{*}$ \\
\hline \multirow{6}{*}{ Kidney } & Caspase-3 & $9.28 \pm 1.80$ & $27.57 \pm 3.95^{*}$ \\
& Caspase-3 Index & $3.32 \pm 0.61$ & $9.22 \pm 1.64^{*}$ \\
& TUNEL & $11.14 \pm 2.27$ & $34.57 \pm 3.69^{*}$ \\
& Apoptotic Index & $3.92 \pm 0.82$ & $11.53 \pm 2.94^{*}$ \\
\hline
\end{tabular}

Immunohistochemical analyses were performed to determine the density and distribution of TrkB and NGFR p75 receptors, respectively. Immunohistochemical staining revealed that the TrkB and NGFR p75 receptors in liver and kidney tissues were in trace amounts, but there was no difference in intensity and distribution of these receptors between the experimental groups (Figure 8-9). 


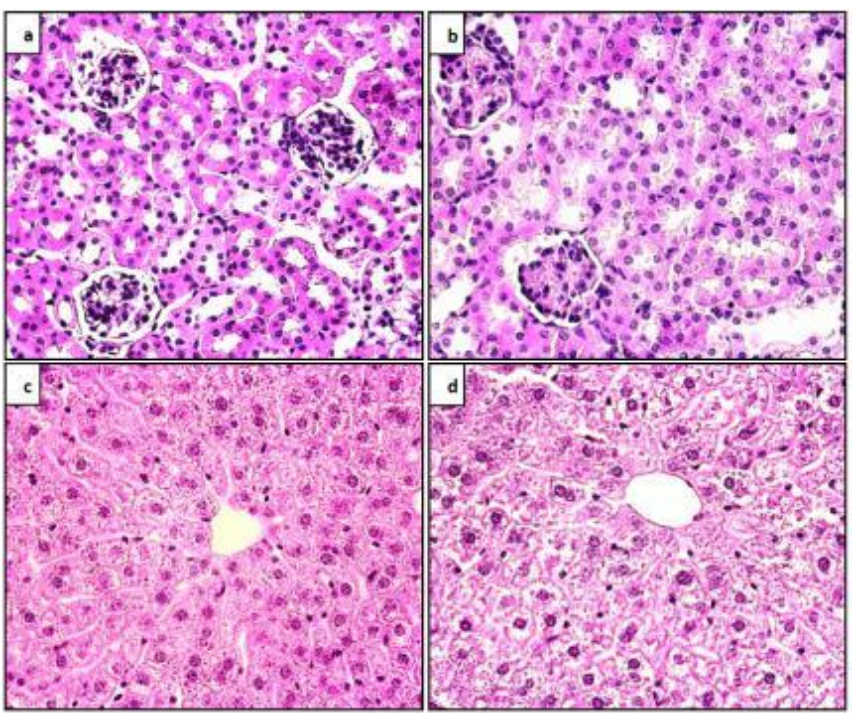

Figure 1: H-E analysis, 40X magnification a) Control kidney tissue b) BDNF heterozygous kidney tissue c) Control liver tissue d) BDNF heterozygous liver tissue

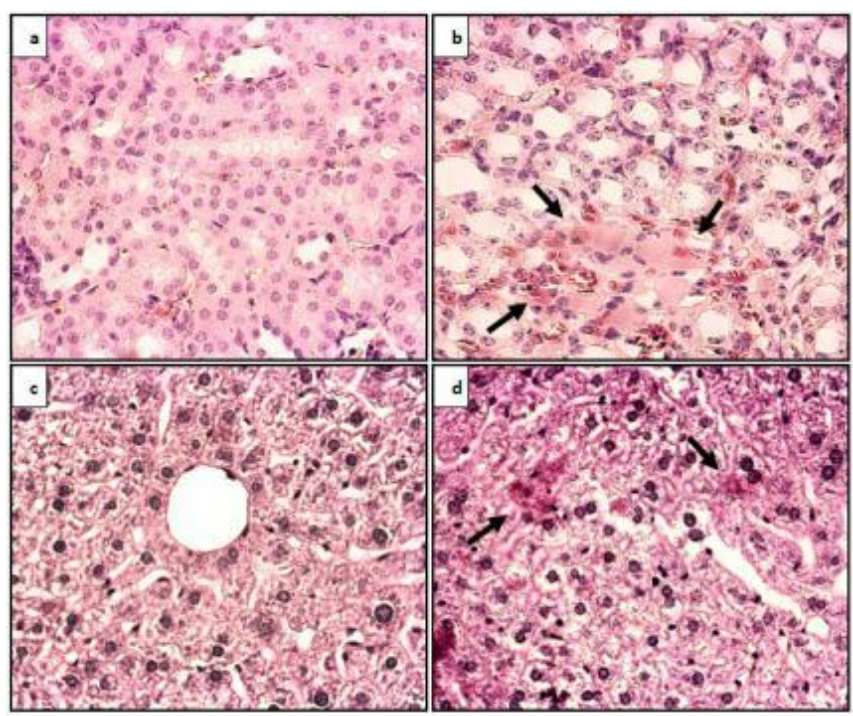

Figure 2: Caspase-3 immunohistochemical analysis, 40X magnification a) Control kidney tissue b) BDNF heterozygous kidney tissue c) Control liver tissue d) BDNF heterozygous liver tissue. Arrows indicate positive staining cells.

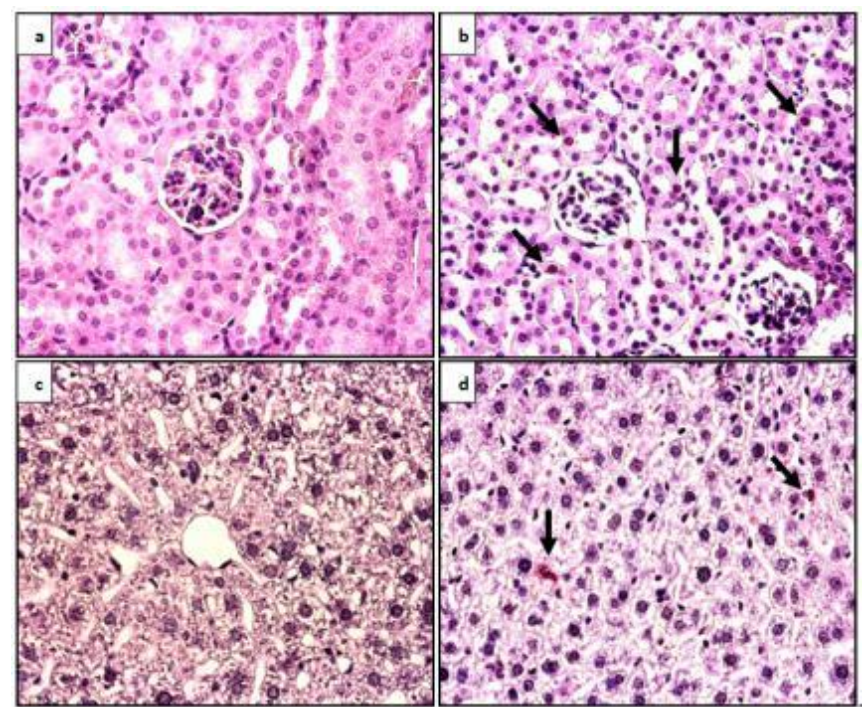

Figure 3: TUNEL immunohistochemical analysis, 40X magnification a) Control kidney tissue b) BDNF heterozygous kidney tissue c) Control liver tissue d) BDNF heterozygous liver tissue. Arrows indicate positive staining cells.

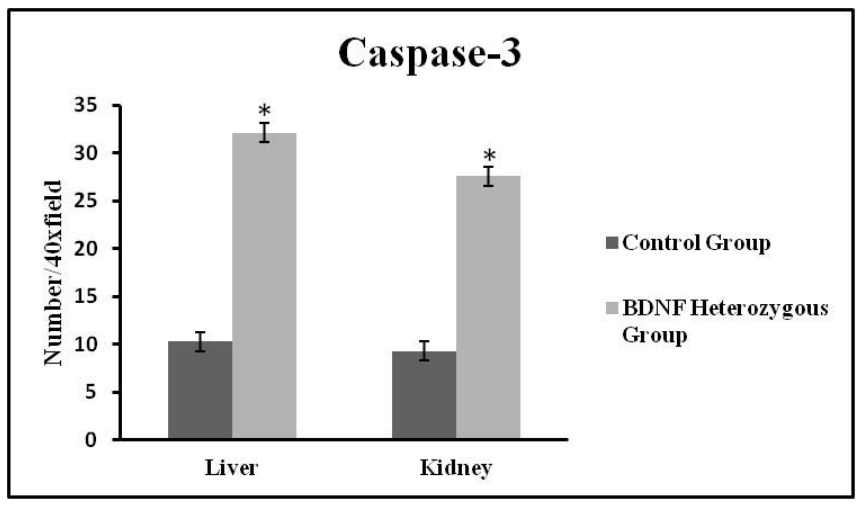

Figure 4: Statistical evaluation of the cell count after the Caspase-3 immunohistochemical analyses applied to liver and kidney tissue sections. ${ }^{*} \mathrm{p}<0.0001$ (compared to control group). 


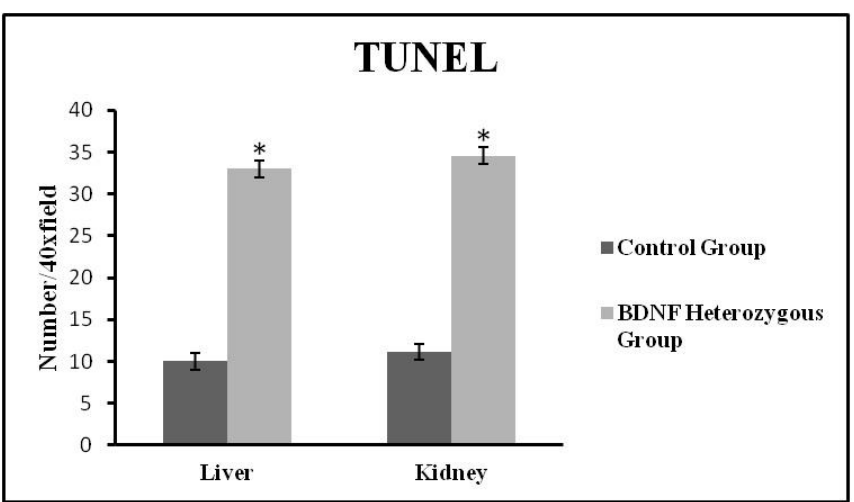

Figure 5: Statistical evaluation of the cell count after the TUNEL immunohistochemical analyses applied to liver and kidney tissue sections. ${ }^{*} \mathrm{p}<0.0001$ (compared to control group).

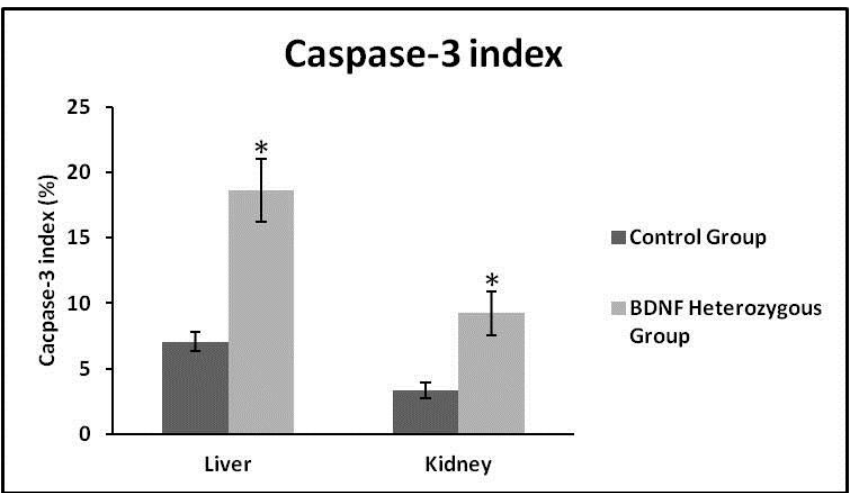

Figure 6: Statistical evaluation of the ratio of Caspase- 3 positive cells to total cells (Caspase- 3 index) after the Caspase-3 immunohistochemical analyses applied to liver and kidney tissue sections. ${ }^{*} \mathrm{p}<0.0001$ (compared to control group).

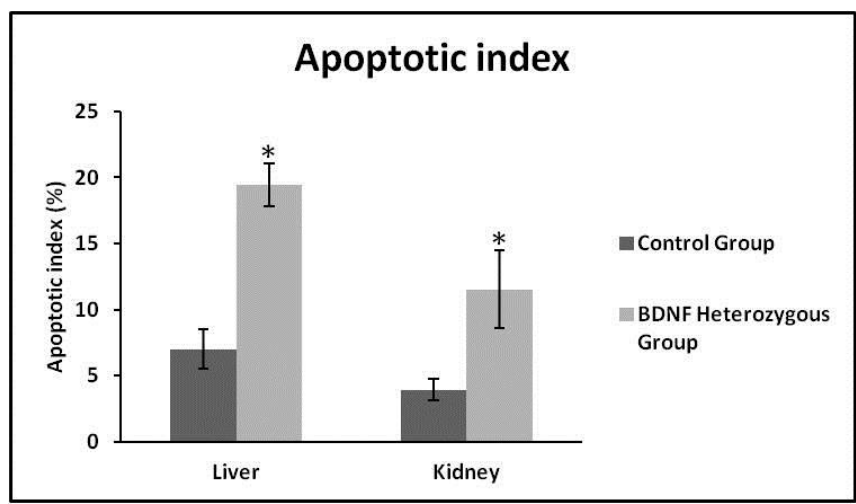

Figure 7: Statistical evaluation of the ratio of TUNEL positive cells to total cells (apoptotic index) after the TUNEL immunohistochemical analyses applied to liver and kidney tissue sections. ${ }^{*} \mathrm{p}<0.0001$ (compared to control group).

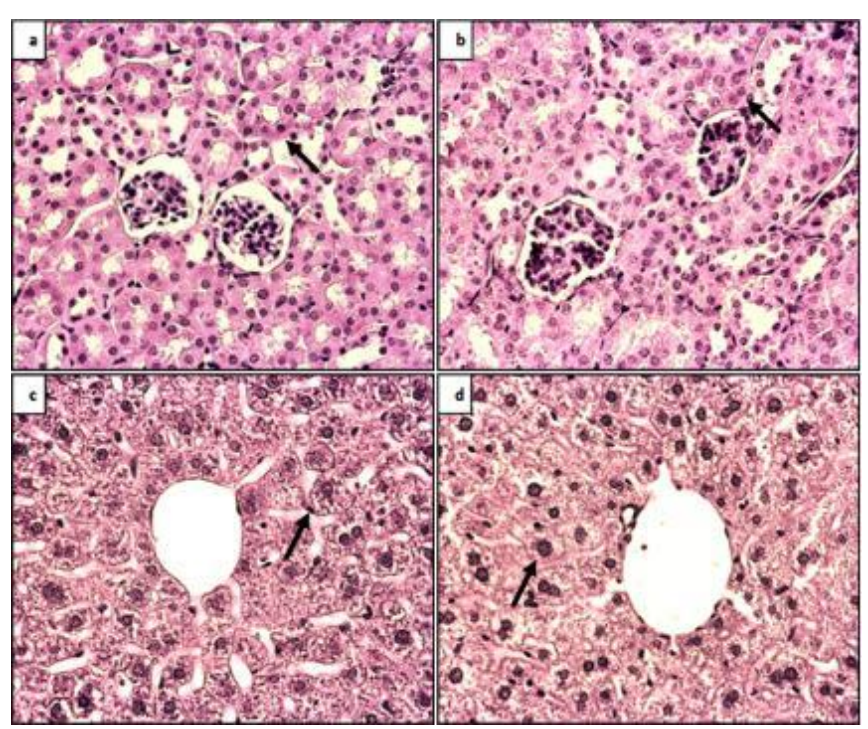

Figure 8: TrkB receptor immunohistochemical analysis, 40X magnification a) Control kidney tissue b) BDNF heterozygous kidney tissue c) Control liver tissue d) BDNF heterozygous liver tissue. Arrows indicate cells showing slight positive staining. 


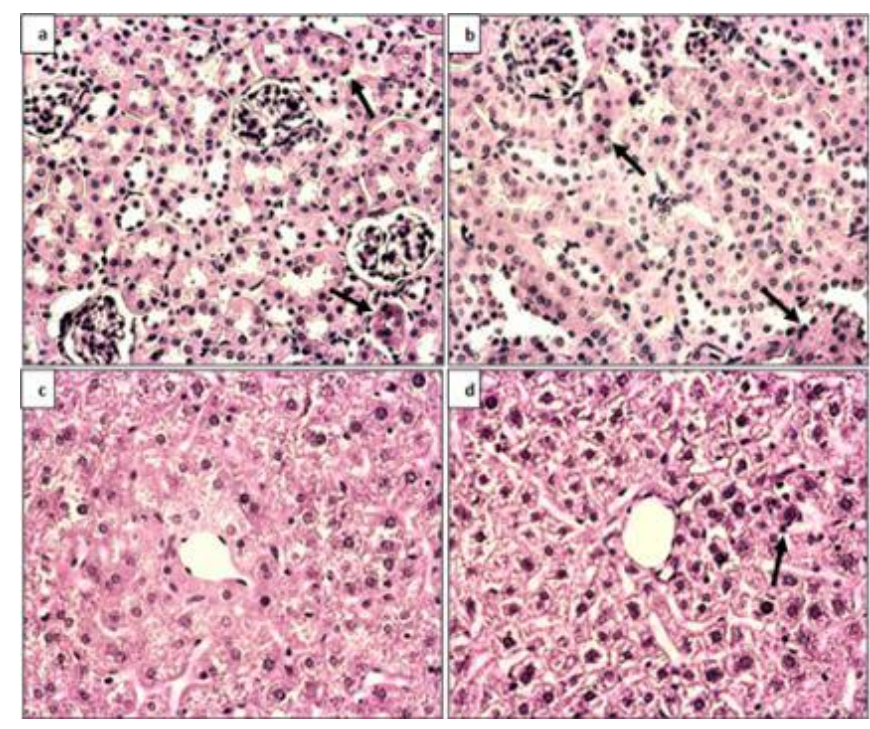

Figure 9: NGFR p75 receptor immunohistochemical analysis, 40X magnification a) Control kidney tissue b) BDNF heterozygous kidney tissue c) Control liver tissue d) BDNF heterozygous liver tissue. Arrows indicate the cell showing slight positive staining.

\section{DISCUSSION}

It is known that BDNF promotes the development and differentiation of neurons and synapses, as well as neuronal survival, by acting on specific neuronal groups in the central and peripheral nervous system ${ }^{8,9}$. Protective effects of BDNF in apoptosis of neuronal cells have been demonstrated by immunofluorescent method by examinating cell survival and nucleus density among groups ${ }^{34}$. It has been reported that administration of BDNF in ischemic damaged brain reduces neuronal death and even supports new neuron formation ${ }^{31}$. In another study, BDNF mRNA and BDNF protein levels were measured in various regions of brain in time-dependent cerebral ischemia, and it was observed that the amount of post-ischemic BDNF mRNA and protein significantly increased in different regions of the brain after ischemia ${ }^{32}$. Different research showed that BDNF, like other neurotrophic factors, protects developing neurons by inhibiting apoptosis during developmental stage $^{30}$. Although the protective effects of BDNF in the nervous system have been demonstrated in many studies, its direct association with apoptosis in peripheral tissues is not known. In this study, histopathological and immunohistochemical studies were performed to determine whether BDNF is protective in liver and kidney tissues, thus the number of cells entering apoptosis was counted and compared between the groups. The histological findings and statistical results obtained after cell counting showed that BDNF prevents apoptosis of cells in liver and kidney, and increases cell survival and contributes to tissue integrity.

Activation of NGFR p75 receptors leads to apoptosis, while activation of TrkB receptors of BDNF in the nervous system increases neuronal survival ${ }^{22}$. It has been reported that the BDNF and TrkB receptors are also expressed in many non-neuronal tissues including muscle, thymus, vascular smooth muscle cells, lung and spleen $^{5,10,14,16,18,19,36}$. However, in a number of different studies it has been found that BDNF receptors are not expressed in peripheral tissues. For example, Shibayama et al. did not found any immunoreactivity against TrkB antibodies in human liver ${ }^{37}$. Again, in other studies conducted by RT-PCR or immunohistochemistry, trace amounts of TrkB receptors have been demonstrated in human or rat liver ${ }^{21,36}$. Lomen-Hoerth and Shooter identified that low levels of the NGFR p75 receptor were expressed in the rat liver, whereas no TrkA or TrkB receptor transcription was presented by using the ribonuclease protection assay ${ }^{16}$. Furthermore, Lommatzsch and colleagues found that BDNF protein expression was presented in many visceral cells, while no BDNF receptor expression was observed in studies in mice ${ }^{17}$. Based on this information, the concentration and distribution of BDNF receptors TrkB and NGFR p75 in liver and kidney tissues were examined. In our study, immunohistochemical stainings revealed that in both groups TrkB and 
NGFR p75 receptors in liver and kidney tissues were determined in trace amounts, but there was no difference in intensity and distribution among the studied groups. It is thought that the BDNF receptor distribution in the liver and kidney tissue may be different from the nervous system, or that BDNF may differ in affinity for these receptors. It may be useful to conduct further research using more detailed and different methods in this regard.

Declaration of Conflicting Interests: The authors declare that they have no conflict of interest.

Financial Disclosure: This study was supported by Giresun University Scientific Research Projects, Giresun TURKEY (Project no: 200515-26 ).

\section{REFERENCES}

1. Binder DK, Scharfman HE. Brain-derived neurotrophic factor. Growth Factors. 2004; 22:123-31.

2. Lewin GR, Barde YA. Physiology of neurotrophins. Annu Rev Neurosci. 1996; 19:289-317.

3. Barde YA, Edgar D, Thoenen H. Purification of a new neurotrophic factor from mammalian brain. EMBO Journal. 1982; 1:549-53.

4. Götz R, Köster R, Winkler C, et al. Neurotrophin-6 is a new member of the nerve growth factor family. Nature. 1994; 372:266-9.

5. Hallböök F, Ibanez CF, Persson H. Evolutionary studies of the nerve growth factor family reveal a novel member abundantly expressed in Xenopus ovary. Neuron. 1991; 6:845-58.

6. Hohn A, Leibrock J, Bailey $\mathrm{K}$, et al. Identification and characterization of a novel member of the nerve growth factor/brain-derived neurotrophic factor family. Nature. 1990; 344:339-41.

7. Abidin I, Eysel UT, Lessmann V, et al. Impaired GABAergic inhibition in the visual cortex of brainderived neurotrophic factor heterozygous knockout mice. J Physiol. 2008; 586:1885-901.

8. Acheson A, Conover JC, Fandl JP, et al. A BDNF autocrine loop in adult sensory neurons prevents cell death. Nature. 1995; 374:450-3.
9. Huang EJ, Reichardt LF. Neurotrophins: Roles in neuronal development and function. Annu Rev Neurosci. 2001; 24:677-736.

10. Matthews VB, Astrom MB, Chan MH, et al. Brain derived neurotrophic factor is produced by skeletal muscle cells in response to contraction and enhances fat oxidation via activation of AMP activated protein kinase. Diabetologia. 2009; 52:1409-18.

11. Krabbe KS, Nielsen AR, Krogh-Madsen R, et al. Brainderived neurotrophic factor (BDNF) and type 2 diabetes. Diabetologia. 2007; 50:431-8.

12. Hacioglu G, Senturk A, Ince I, et al. Assessment of oxidative stress parameters of brain-derived neurotrophic factor heterozygous mice in acute stress model. Iran J Basic Med Sci. 2016; 19:388-93.

13. Yamada K, Nabeshima T. Brain-derived neurotrophic factor/TrkB signaling in memory processes. J Pharmacol Sci. 2003; 91:267-70.

14. Cassiman D, Denef C, Desmet VJ, et al. Human and rat hepatic stellate cells express neurotrophins and neurotrophin receptors. Hepatology. 2001; 33:148-58.

15. Guo D, Hou X, Zhang $\mathrm{H}$, et al. More expressions of BDNF and TrkB in multiple hepatocellular carcinoma and anti-BDNF or K252a induced apoptosis, supressed invasion of HepG2 and HCCLM3 cells. J Exp Clin Cancer Res. 2011; 30:97-105.

16. Lomen-Hoerth C, Shooter EM. Widespread neurotrophin receptor expression in the immune system and other nonneuronal rat tissues. J Neurochem. 1995; 64:1780-9.

17. Lommatzsch $M$, Braun A, Mannsfeldt A, et al. Abundant production of brain-derived neurotrophic factor by adult visceral epithelia. Implications for paracrine and target derived neurotrophic functions. Am J Pathol. 1999; 155:1183-93.

18. Mousavi $\mathrm{K}$, Jasmin BJ. BDNF is expressed in skeletal muscle satellite cells and inhibits myogenic differentiation. J Neurosci. 2006; 26:5739-49.

19. Serra-Millas M. Are the changes in the peripheral brain-derived neurotrophic factor levels due to platelet activation? World J Psychiatry. 2016; 6:84-101.

20. Vivacqua G, Renzi A, Carpino G, et al. Expression of brain derivated neurotrophic factor and of its receptors: TrKB and p75NT in normal and bile duct ligated rat liver. Ital J Anat Embryol. 2014; 119:111-29.

21. Zhou XF, Rush RA. Localization of neurotrophin-3like immunoreactivity in peripheral tissues of the rat. Brain Res. 1993; 621:189-99.

22. Barrett GL. The p75 neurotrophin receptor and neuronal apoptosis. Prog Neurobiol. 2000; 61:205-29. 
23. Friedman WJ. Neurotrophins induce death of hippocampal neurons via the p75 receptor. J Neurosci. 2000; 20:6340-46.

24. Nagahara AH, Tuszynski MH. Potential therapeutic uses of BDNF in neurological and psychiatric disorders. Nat Rev Drug Discov. 2011; 10:209-19.

25. Ukropec J, Ukropcova B, Kurdiova T, et al. Adipose tissue and skeletal muscle plasticity modulates metabolic health. Arch Physiol Biochem. 2008; 114:357-68.

26. Cummings MC, Winterfold CM, Walker NI. Apoptosis. Am J Surg Pathol. 1997; 21:88-101.

27. Mak T. The E. Donnall Thomas Lecture-apoptosis: "tis death that makes life live". Biol. Blood Marrow Transplant. 2003; 9:483-8.

28. Elmore S. Apoptosis: A review of programmed cell death. Toxicol. Pathol. 2007; 35:495-516.

29. Güleş Ö, Eren Ü. [Methods for Detection of Apoptosis]. Y.Y.Ü.Veteriner Fakültesi Dergisi. 2008; 2:73-8.

30. Wyllie AH, Kerr JF, Currie AR. Cell death: the significance of apoptosis. Int Rev Cytol. 1980; 68:251306.

31. Beck T, Lindholm D, Castren E, et al. Brain-derived neurotrophic factor protects against ischemic cell damage in rat hippocampus. J Cereb Blood Flow Metab. 1994; 14:689-92.

32. Kokaia Z, Nawa H, Uchino H, et al. Regional brainderived neurotrophic factor mRNA and protein levels following transient forebrain ischemia in the rat. Brain Res Mol Brain Res. 1996; 38:139-44.

33. Thornberry NA, Lazebnik Y. Caspases: enemies within. Science. 1998; 281:1312-16.

34. Almeida RD, Manadas BJ, Melo CV, et al. Neuroprotection by BDNF against glutamate-induced apoptotic cell death is mediated by ERK and PI3-kinase pathways. Cell Death Differ. 2005; 12:1329-43.

35. Korte M, Carroll P, Wolf E, et al. Hippocampal longterm potentiation is impaired in mice lacking brainderived neurotrophic factor. Proc Natl Acad Sci USA. 1995; 92:8856-60.

36. Yamamoto M, Sobue G, Yamamoto K, et al. Expression of mRNAs for neurotrophic factors (NGF, BDNF, NT-3, and GDNF) and their receptors (p75NGFR, TrKA, TrKB, and $\operatorname{TrKC}$ ) in the adult human peripheral nervous system and nonneural tissues. Neurochem Res. 1996; 21:929-38.

37. Shibayama E, Koizumi H. Cellular localization of the TrK neurotrophin receptor family in human nonneuronal tissues. Am J Pathol. 1996; 148:1807-18. 